\title{
Analysis of Different Rare Metals, and Rare Earth Metals in Harvested Rain Water in Gaza Strip/Palestine by ICP/MS-Data and Health Aspects
}

\author{
M. A. Al-Qutob1,2* , F. Al-Rimawi ${ }^{3}$ \\ ${ }^{1}$ Department of Earth and Environmental Studies, Faculty of Science and Technology, Al-Quds University, East Jerusalem, Palestine \\ ${ }^{2}$ Aquatic and Aquaculture Research Laboratory, Al-Quds University, East Jerusalem, Palestine \\ ${ }^{3}$ Chemistry Department, Faculty of Science and Technology, Al-Quds University, East Jerusalem, Palestine \\ Email: ${ }^{\star}$ kutob@staff.alquds.edu
}

How to cite this paper: Al-Qutob, M.A. and Al-Rimawi, F. (2016) Analysis of Different Rare Metals, and Rare Earth Metals in Harvested Rain Water in Gaza Strip/Palestine by ICP/MS-Data and Health Aspects. Journal of Water Resource and Protection, 8, 905-912.

http://dx.doi.org/10.4236/jwarp.2016.810074

Received: July 14, 2016

Accepted: September 3, 2016

Published: September 8, 2016

Copyright $\odot 2016$ by authors and Scientific Research Publishing Inc. This work is licensed under the Creative Commons Attribution International License (CC BY 4.0).

http://creativecommons.org/licenses/by/4.0/ c) (i) Open Access

\begin{abstract}
This rain water samples harvested for drinking and agriculture from Gaza collected in November 2012 were analyzed for different rare metals ( $\mathrm{Rb}, \mathrm{Zr}, \mathrm{Ti}, \mathrm{Tl}, \mathrm{Sb}, \mathrm{Sc}, \mathrm{Y}$ ), and rare earth metals ( $\mathrm{La}$, and $\mathrm{Ce}$ ). These metals usually have no maximum acceptable limits as there is no sufficient data about their toxicity to human health. Their control should be therefore controlled in water to monitor their concentration in water (ground, harvested, etc.). This study was conducted to determine the water quality of harvested water which is used for drinking in the study area. 43 water samples were collected in November 2012 during the first rain from house wells and rain water pools. The concentrations of the metals detected in the collected harvested rainwater vary significantly between the 43 samples, and all of them were detected in all water samples analyzed in this study. The results obtained from this study suggest a possible risk to the population of the study area given the high concentration of some metals that have no maximum allowed concentration, and the fact that for many people in the study area, harvested rain water is a main source of their water supply.
\end{abstract}

\section{Keywords}

Rare Metals, Rare Earth Elements, WHO Limits, ICP/MS, Gaza Strip, Harvested Rain Water 


\section{Introduction}

The importance of water for man makes management of this natural resource a priority in order to preserve its sustainability. Water analysis plays a decisive role in regulations that determine the water quality levels for different uses e.g., for drinking water [1]. Water analysis is applicable also to the study of water origin and evolution, taking into account the natural and anthropic influences, e.g. water-water and water-rock interactions, contamination processes, etc.

Occurrence of metals in water is sensitive to anthropic influences [2]. Therefore, it is reported that the concentrations of rare metals in water have been increased as a result of human and anthropogenic activities [3]-[6].

The advances in analytical techniques facilitate the application of the hydrochemical fingerprint concept. Inductively coupled plasma-mass spectrometry (ICP-MS) is particularly suitable for this purpose due to the possibility of rapid multielement analysis in combination with excellent detection limits [7]-[10]. The ICP-MS allows one to obtain complete information on the trace elements occurring in water, including those present in sub-ppb concentrations.

Drinking water contamination with metals is important environmental issue as some are toxic even at low concentrations [11]-[13]. From the rare metals analyzed in this study, antimony $\mathrm{Sb}$, cerium Ce, thallium $\mathrm{Tl}$ [14], which are heavy metals, are of concern because of occupational or residential exposure. Heavy metals are well known to be toxic to human beings as they are not metabolized by the body and so accumulate in the soft tissues. These metals may enter the human body via different routes and including water [15] [16].

This work is a continuation of a previous work where metal contamination of the harvested rain water of Gaza strip in Palestine was assessed by analysis of different heavy metals ( $\mathrm{Ba}, \mathrm{Cu}, \mathrm{Zn}, \mathrm{Co}, \mathrm{Mn}, \mathrm{V}, \mathrm{Al}, \mathrm{Pb}, \mathrm{Cr}, \mathrm{Ni}, \mathrm{As}, \mathrm{U}$, and $\mathrm{Cd}$ ) and results showed that 8 trace metals is higher than the allowed WHO limits in drinking water. The present paper reports analytical results for some rare metals $(\mathrm{Rb}, \mathrm{Zr}, \mathrm{Ti}, \mathrm{Tl}, \mathrm{Sb}, \mathrm{Sc}, \mathrm{Y})$, and rare earth metals ( $\mathrm{La}$, and $\mathrm{Ce}$ ) which have no maximum allowed concentrations by WHO or any other regulation agencies.

\section{Experimental}

\subsection{Study Area}

First, Gaza Strip is a strip of land on the eastern coast of the Mediterranean Sea, located in the Middle East (at latitudes $31^{\circ} 16^{\prime \prime} \mathrm{N}$ and $31^{\circ} 45^{\prime \prime} \mathrm{N}$ and longitudes $34^{\circ} 20^{\prime \prime} \mathrm{E}$ and $34^{\circ} 25^{\prime} \mathrm{E}$ ) [17] bordered by the Mediterranean Sea in the West and the Negev Desert and Egyptian Sinai Peninsula in the South with a total area of $365 \mathrm{Km}^{2}$. For administrative purposes; the area has been divided into five regions: North, Gaza, Middle, Khan Younis and Rafah. Each governorate consists of municipalities that varied in number depending on the number of towns or villages and the population of each. Gaza Strip is one of the most densely populated areas in the world, 4505 people per $\mathrm{km}^{2}$.

Gaza's water resources are essentially limited to that part of the coastal aquifer that 
underlies its area [18].

Regarding the topography of Gaza strip, it is a coastal foreshore plain according to a Topography that refers to the altitude of the land surface. The topography of the area is flat, where the altitude of the Gaza Strip land surface ranges between zero meters at the shore line to about 90 meters above means sea level in some places. The height increases towards the east from 20 to 90 meter above the sea level.

Generally; the climate of Palestine is of East Mediterranean type; identified as being hot and humid in a summer and cold in winter. The US Environmental Agency has classified regions into arid and non-arid regions based on rainfall of $12.5 \mathrm{in} / \mathrm{yr}$ (312.5 $\mathrm{mm} /$ year) to be the reference [19].

The area has a Mediterranean dry summer sub topical climate with mild winter; this is because of its locations as transitional zone between semi-humid Mediterranean climate and arid desert climate. The highest mean annual temperature is $30.85^{\circ} \mathrm{C}$ in $\mathrm{Au}$ gust, while the lowest mean annual temperature is $13.50^{\circ} \mathrm{C}$ in January, with the mean annual temperature of $19.90^{\circ} \mathrm{C}$ [20].

\subsection{Sampling and Analysis}

The Sampling has been carried out in November 2012 (the beginning of the rain season) where 43 water samples were collected from 43 house wells and rain water pools. Figure 1 shows the location of the part of Gaza where the samples were taken, and the location of the cisterns analyzed in this study. The water samples were collected in 1-liter high density polyethylene bottles (pre-cleaned with $10 \%$ nitric acid followed by

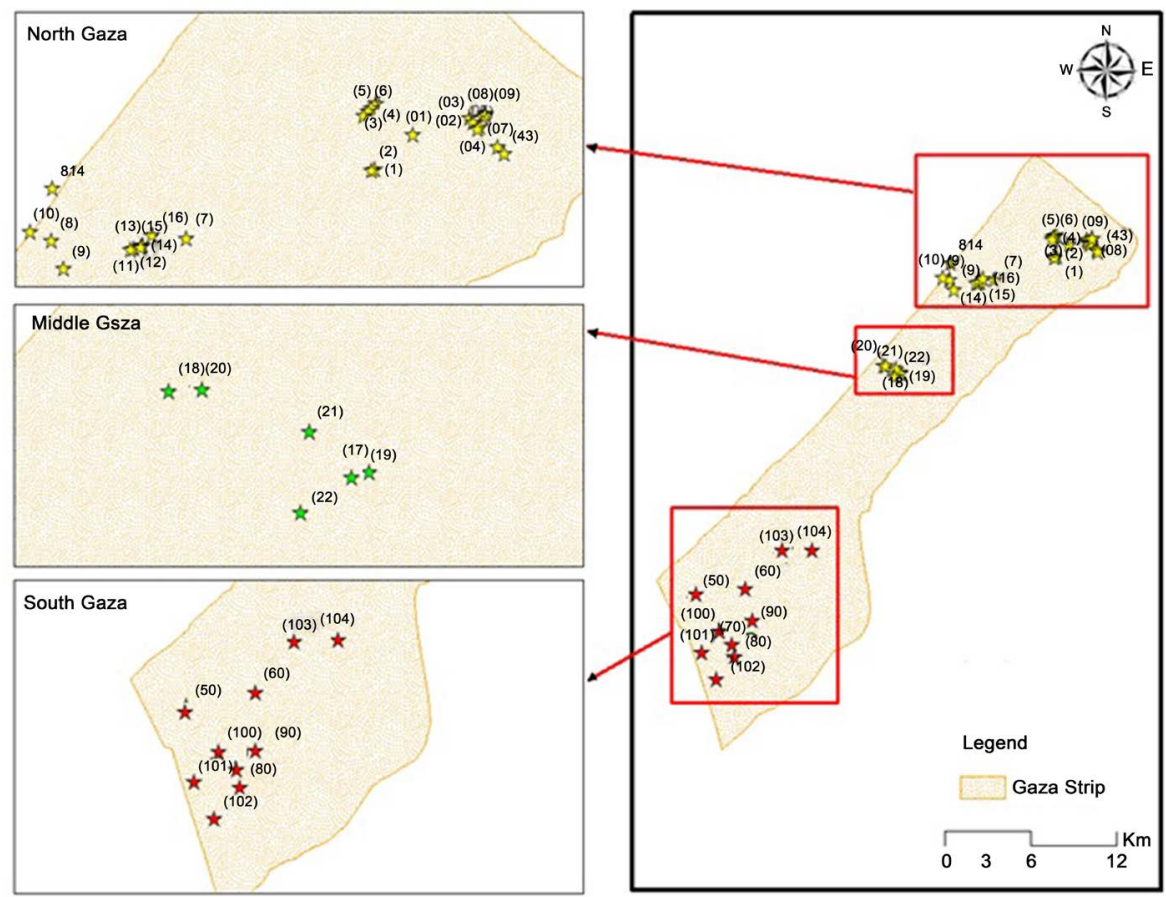

Figure 1. Map of gaza strip showing the location of house wells and rain water pools (marked with ${ }^{\star}$ ) containing harvested rain water analyzed in this work. 
repeated rinsing with bi-distilled water), stabilized with ultrapure nitric acid (0.5\% $\mathrm{HNO}_{3}$ ), preserved in a cool place (about $4^{\circ} \mathrm{C}$ ) and transported to the lab of AlQuds University for further analysis.

For accurate quantitative determination of heavy metals in water samples, an internal standard method was used using $\mathrm{Nd}$ as internal standard and a multi-standard calibration method ( 29 metals standard, matrix $5 \% \mathrm{HNO}_{3}$ ). Samples were prepared by dilution of $1.0 \mathrm{ml}$ of the water samples to $10.0 \mathrm{~mL}$ with $0.3 \%$ ultrapure nitric acid and analyzed by ICP/MS. Each sample was analyzed three times and the results are expressed as mean \pm SD (SD: standard deviation). Relative standard deviation (RSD) of the three results are calculated and found to be less than $5 \%$ for all samples for all heavy metals analyzed in this study, reflecting the precision of the method for the analysis of these heavy metals. Calibration curves for all heavy metals analyzed were constructed by plotting the ratio of the intensity of the analyte heavy metal to that of the internal standard vs. concentration of the heavy metal (in ppb), and results showed that the calibration curves are linear with correlation coefficient $\left(r^{2}\right)$ greater than 0.999 for the heavy metals analyzed with a concentration range of $1-1000 \mathrm{ppb}$.

\subsection{The Instrument}

The Agilent Technologies 7500 Series ICP-MS (Agilent 7500) can measure trace elements as low as one part per trillion (ppt) and quickly scan more than 70 elements to determine the composition of an unknown sample with a Mass Hunter Workstation software automates the analysis and accurately interprets the resulting data. The ICP/MS instrument consists of an on-board peristaltic pump that controls the flow of sample solution into and waste (drain) out of the instrument, a nebulizer (Micro Mist nebulizer) that uses a stream of argon to disperse the sample, an ICP Argon plasma torch using Argon as plasma gas, auxillary gas and nebulizer (carrier) gas, two pumps for evacuation, Quadrupole mass analyzer with unit resolution, an octapole reaction system (ORS), and electron multiplier detector.

\section{Results and Discussion}

Before this study was conducted to investigate the quality of harvested rainwater from Gaza in November 2012 in terms of their trace rare metals content since harvested rainwater is used for drinking and agriculture in Gaza as Gaza is located in the semiarid region and it is one of the scarce water countries in Middle East. Additionally this study was conducted to monitor rare metals in harvested rain water as there are no sufficient studies conducted on the concentration of such rare metals in water (ground, drinking, harvested water).

The detection limits of the studied metals are reported in Table 1, and are three times the standard deviation estimated from six replicate measurements of the blank ( $1 \% \mathrm{v} / \mathrm{v}$ HNO3). The detection limits by ICP-MS range between 0.01 and $0.10 \mathrm{ppb}$ for the trace metals analyzed in this study.

ICP/MS analysis results showed that all trace metals ( $\mathrm{Rb}, \mathrm{Zr}, \mathrm{Ti}, \mathrm{Tl}, \mathrm{Sb}, \mathrm{Sc}, \mathrm{Y}, \mathrm{La}, \mathrm{Ce}$ ) 
Table 1. Concentration (in ppb) of different rare metals detected in harvested rainwater analyzed in this study.

\begin{tabular}{cccccccc}
\hline Metal & $\begin{array}{c}\text { LOD } \\
(\mathrm{ppb})\end{array}$ & $\begin{array}{c}\text { Minimum } \\
(\mathrm{ppb})\end{array}$ & $\begin{array}{c}\text { Median } \\
(\mathrm{ppb})\end{array}$ & $\begin{array}{c}\text { Maximum } \\
(\mathrm{ppb})\end{array}$ & $\begin{array}{c}\text { Average } \\
(\mathrm{ppb})\end{array}$ & SD & Limits \\
\hline $\mathrm{Rb}$ & 0.01 & 0.77 & 6.41 & 49.07 & 7.84 & 7.92 & No limits \\
$\mathrm{Zr}$ & 0.01 & 0.12 & 0.96 & 13.21 & 2.1 & 3.1 & No limits \\
$\mathrm{Ti}$ & 0.02 & 0.83 & 4.31 & 1537.5 & 60.4 & 236.2 & No limits \\
$\mathrm{Tl}$ & 0.01 & 0.02 & 0.03 & 0.06 & 0.014 & 0.013 & No limits \\
$\mathrm{Sb}$ & 0.04 & 0.14 & 1.09 & 8.16 & 1.60 & 1.72 & No limits \\
$\mathrm{Sc}$ & 0.05 & 0.08 & 0.57 & 10.05 & 1.25 & 2.25 & No limits \\
$\mathrm{Y}$ & 0.10 & 0.27 & 2.40 & 128.71 & 12.15 & 26.43 & No limits \\
$\mathrm{La}$ & 0.01 & 0.16 & 2.03 & 89.32 & 9.17 & 18.81 & No limits \\
$\mathrm{Ce}$ & 0.01 & 0.34 & 4.19 & 153.30 & 16.70 & 33.72 & No limits \\
\hline
\end{tabular}

were detected in all water samples analyzed in this study. All of them are heavy metals except $\mathrm{Rb}$, and $\mathrm{Sb}$ (they are metals but not heavy metals). The concentration (in ppb) of these metals were found to be in the range of: $0.77-49.07,0.12-13.21,0.83-1537.5$, $0.02-0.06,0.14-8.16,0.08-10.05,0.27-128.71,0.16$ - 89.32, and $0.34-153.30$, for Rb, $\mathrm{Zr}, \mathrm{Ti}, \mathrm{Tl}, \mathrm{Sb}, \mathrm{Sc}, \mathrm{Y}, \mathrm{La}$, and Ce respectively, see Table 1.

Table 1 summarizes concentrations (minimum, median, maximum, average, and standard deviation) of the trace metals ( $\mathrm{Rb}, \mathrm{Zr}, \mathrm{Ti}, \mathrm{Tl}, \mathrm{Sb}, \mathrm{Sc}, \mathrm{Y}, \mathrm{La}$, and $\mathrm{Ce}$ ) for the harvested rainwater samples analyzed in this study. As it is seen from this table, there is a significant difference between the average and median values indicating that there are differences in the concentrations of the metals in the water samples analyzed in this study. A one way ANOVA statistical test was used to test if the concentration of metals is significantly different in the 43 water samples analyzed. Results showed that all metals concentrations are significantly different in the 43 water samples at $95 \%$ confidence level. This indicates that these water samples are different from each other in terms of heavy metals concentration. This result confirms locational variations of heavy metals in the water samples analyzed in this study. Figures 2-4 shows the concentration of $\mathrm{Tl}$, $\mathrm{Sb}$, and Ce detected in the 43 water samples analyzed in this study.

No drinking water standards are defined by EU, WHO or US EPA for these metals. Several of these metals have documented health effects [21]. For others, for example the rare earth elements, knowledge about health effects are rather limited [21]. However all of these metals are detected in all harvested rainwater samples analyzed in this study. Additionally, some of these metals are unexpectedly and surprisingly detected with high concentrations e.g. Ti, Ce, Y, see Table 1. In addition to the potential pollution of harvested rainwater with these rare metals, the concentrations of these elements which are low in natural waters, are of particular interest to fingerprint the water sources [22].

\section{Conclusion}

High concentrations are observed for a number of rare metals for which no maximum 


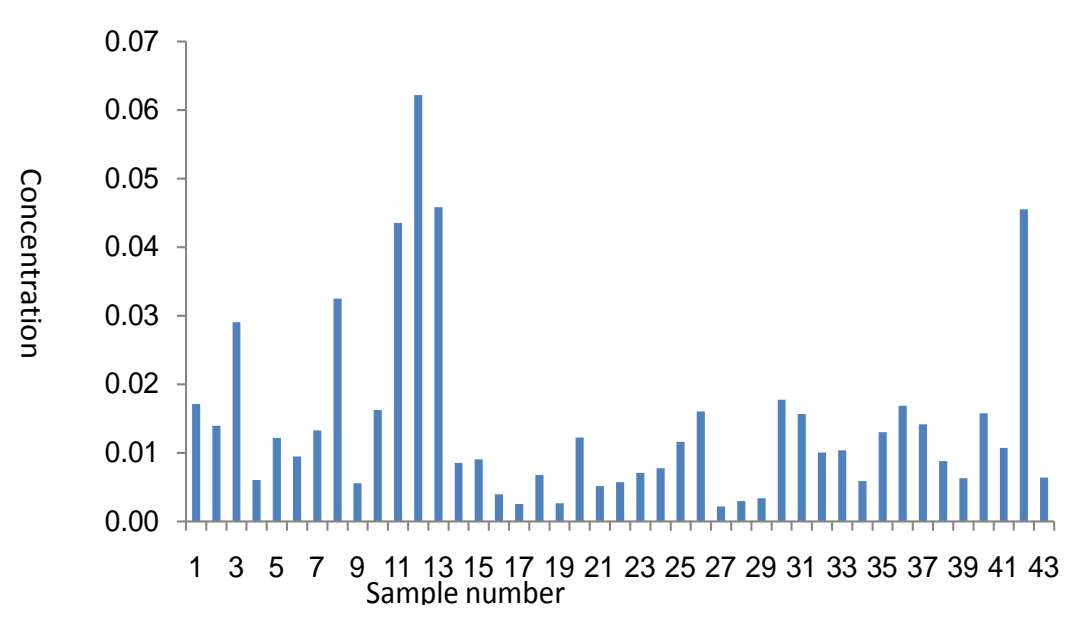

Figure 2. Concentrations of thallium (Tl) detected in the 43 water samples analyzed in this study by ICP-MS.

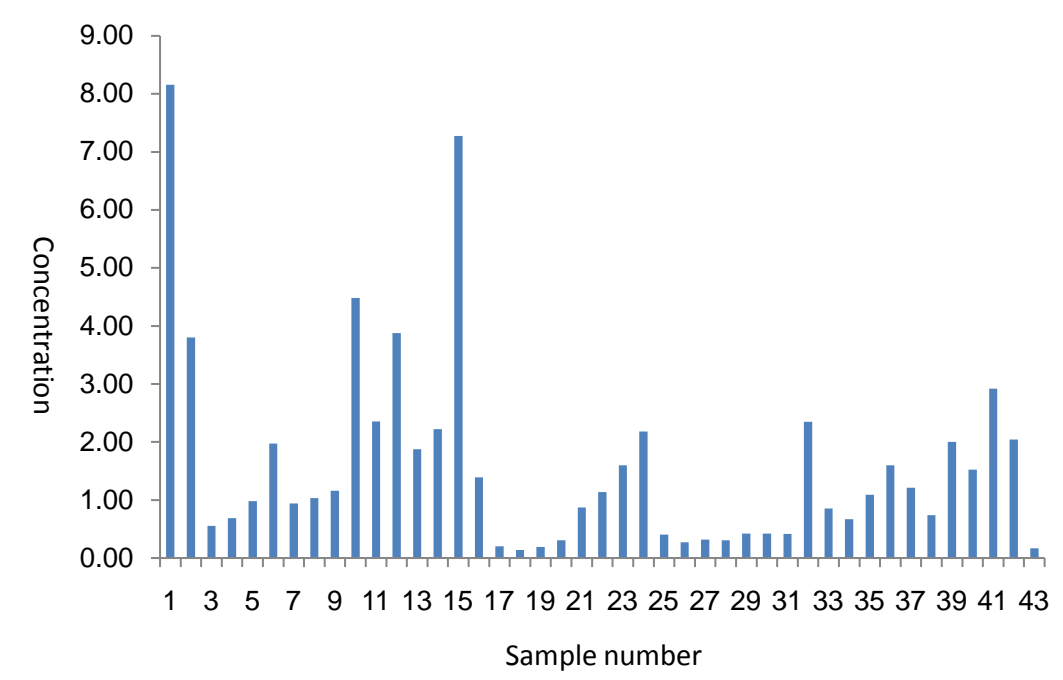

Figure 3. Concentrations of antinomy ( $\mathrm{Sb}$ ) detected in the 43 water samples analyzed in this study by ICP-MS.

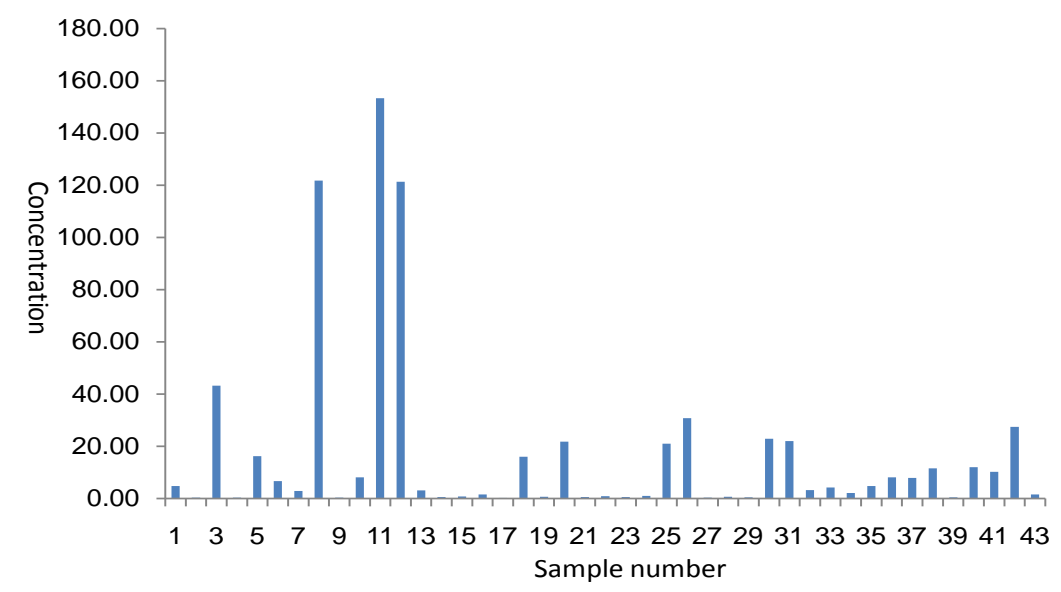

Figure 4. Concentrations of antinomy (Ce) detected in the 43 water samples analyzed in this study by ICP-MS. 
allowed concentration values have been proposed (e.g., $\mathrm{Ti}, \mathrm{Ce}$, and $\mathrm{Y}$ ). These metals may warrant a toxicological assessment. These metals need urgent attention from a health perspective. Public authorities might be well advised to establish maximum allo-wed limits for such metals. This study demonstrates the necessity of documenting natural metal concentrations and variation in drinking water resources on a regional scale. This must be carried out for as many elements as can be analyzed with today's techniques in different water sources, to provide finger-prints of the different types of water.

\section{Acknowledgements}

The authors are grateful to the Association of Arab Universities for their financial support. The authors would like also to thank the volunteers at MECA (Middle East Children's Alliance) who worked tirelessly on short notice to mobilize volunteers and collect water samples across the entire Gaza strip during the first rain after the bombings in November, 2012.

\section{References}

[1] EU (European Union) Directive 98/83/EC on the Quality of Water Intended for Human Consumption. OJ, L330, December 1998.

[2] Misund, A., Frengstad, B., Siewers, U. and Reimann, C. (1999) Natural Variation of 66 Elements in European Mineral Waters. Science Total Environment, 243, 21-41. http://dx.doi.org/10.1016/S0048-9697(99)00307-1

[3] Batayneh, A.T. (2010) Heavy Metals in Water Springs of the Yarmouk Basin, North Jordan and Their Potentiality in Health Risk Assessment. International Journal of the Physical Sciences, 5, 997-1003.

[4] Abderahman, N. and Abu-Rukah, Y. (2006) An Assessment Study of Heavy Metal. Environmental Geology, 49, 1116-1124.

[5] Adekunle, I.M., Adetunji, M.T., Gbadebo, A.M. and Banjoko, O.B. (2007) Assessment of Groundwater Quality in a Typical Rural Settlement in Southwest Nigeria. International Journal of Environmental research and Public Health, 4, 307-318.

[6] Chen, C., Kao, C., Chen, C. and Dong, C. (2007) Distribution and Accumulation of Heavy Metals in the Sediments of Kaohsiung Harbor, Taiwan. Chemosphere, 66, 1431-1440. http://dx.doi.org/10.1016/j.chemosphere.2006.09.030

[7] Kim, I. and Kim, G. (2011) Large Fluxes of Rare Earth Elements through Submarine Groundwater Discharge (SGD) from a Volcanic Island, Jeju, Korea. Marine Chemistry, 127, 12-19. http://dx.doi.org/10.1016/j.marchem.2011.07.006

[8] Janssen, R.P. and Verweij, W. (2003) Geochemistry of Some Rare Earth Elements in Groundwater, Vierlingsbeek, The Netherlands. Water Research, 37, 1320-1350. http://dx.doi.org/10.1016/S0043-1354(02)00492-X

[9] Gruau, G.G., Dia, A., Olivie-Lauquet, G., Davranche, M. and Pinay, G. (2004) Controls on the Distribution of Rare Earth Elements in Shallow Ground Waters. Water Research, 38, 3576-3586. http://dx.doi.org/10.1016/j.watres.2004.04.056

[10] Rasheed, M.A., Radha, B.A., SrinivasaRao, P.L., Lakshmi, M., Chennaiah, J.B. and Dayal, A.M. (2012) Evaluation of Potable Groundwater Quality in Some Villages of Adilabad in Andhra Pradesh, India. Journal of Environmental Biology, 33, 689-693. 
[11] Momodu, M.A. and Anyakora, C.A. (2010) Heavy Metal Contamination of Ground Water: The Surulere Case Study. Research Journal Environmental and Earth Sciences, 2, 39-43.

[12] Vodela, J.K., Renden, J.A., Lenz, S.D., McElhenney, W. and Kemppainen, B. (1997) Drinking Water Contaminants (Arsenic, Cadmium, Lead, Benzene, and Trichloroethylene). 1. Interaction of Contaminants with Nutritional Status on General Performance and Immune Function in Broiler Chickens. Poultry Science, 76, 1474-92.

http://dx.doi.org/10.1093/ps/76.11.1474

[13] Marcovecchio, J.E., Botte, S.E. and Freije, R.H. (2007) Heavy Metals, Major Metals, Trace Elements. In: Nollet, L.M., Ed., Handbook of Water Analysis, 2nd Edition. CRC Press, London, 275. http://dx.doi.org/10.1201/9781420006315.ch11

[14] Ferner, D.J. (2001) Toxicity and Heavy Metals. eMedicine Journal, 2 ,1.

[15] Roberts, H. (1999) Lead Poisoning. http://www.setlet.com

[16] Dupler, D. (2001) Heavy Metal Poisoning. Gale Encyclopedia of Alternative Medicine, Farmington Hills, Gale Group.

[17] Aish, A. and Smedt, De. (2004) Hydro Geological Study and Artificial Recharge Modeling of the Gaza Coastal Aquifer Using GIS and MODFLOW. Ph.D. Thesis, Vrije Universiteit Brussel, Brussels.

[18] Al-Talmas, M. and Mogheir, Y. (2012) Risk Assessment and Mitigation of the Seawater Intrusion Using Modeling Approach, Islamic University of Gaza, Gaza Strip, Palestine.

[19] Ashour, E. and Al-Najar, H. (2012) The Impact of Climate Change and Soil Salinity in Irrigation Water Demand in the Gaza Strip. Journal of Earth Science \& Climatic Change, 3, 120. http://dx.doi.org/10.4172/2157-7617.1000120

[20] Khalaf, A. (2005) Assessment of Rainwater Losses due to Urban Expansion of Gaza Strip. M.Sc. Thesis, The Islamic University, Gaza.

[21] Reimanna, C., Bjorvatnb, K., Frengstada, B., Melakuc, Z., Tekle-Haimanotc, R. and Siewersd, U. (2003) Drinking Water Quality in the Ethiopian Section of the East African Rift Valley I-Data and Health Aspects. The Science of the Total Environment, 311, 65-80. http://dx.doi.org/10.1016/S0048-9697(03)00137-2

[22] Smedley, P.L. and Kinniburgh, D.G. (2002) A Review of the Source, Behavior and Distribution of Arsenic in Natural Waters. Applied Geochemistry, 17, 517-568. http://dx.doi.org/10.1016/S0883-2927(02)00018-5 